\title{
Relevance of China's Reform Experience to India
}

\author{
Ishfaq Ahmad MAIIK ${ }^{1}$, Ajaz Ahmad RATHER ${ }^{2}$, Tibebu Alemu TEKLE ${ }^{3}$
}

Received: September 01, 2020 Revised: October 26, 2020 Accepted: November 16, 2020

\begin{abstract}
The aim of this paper is to understand the nature of transformation of the Chinese economy. China's approach to the process of economic development in the aftermath of the reforms in the late 1970's has been a success story and a phenomenon of great significance. It helped millions of people move out of poverty and achieve an acceptable standard of life. The economic policy of China was more effective than India's; we measured this effectiveness in terms of two fundamental approach: first, growth was fundamental for ensuring and increasing the wellbeing as it increases total output in China compare to India; second, growth was pro-poor in China, but not in India, during the period 2000-2011. In this paper, we seek to explain how China reduced extreme poverty through reforms, and this reform experience of China stands out for three reasons. The first is renewed thrust on the rural economy and private sector, second is decentralized planning, and third is investment in human resource development. This experience of China's reform success offers a significant lesson for most of the developing countries, especially India, since India has more similarities with China. Therefore, this experience is particularly insightful for India.
\end{abstract}

Keywords: Pro-Poor Growth, Growth Accounting, Economic Reforms, China, India

JEL Classification Code: U12, S21, A13

\section{Introduction}

The independence of countries in the mid-twentieth century from colonial powers created both opportunities and challenges of development planning. After the breakup of the Soviet Union, newly-independent countries were confronted with the onus of making the same difficult choices. In the beginning the issue was supposed to be macro structuring of economy for a perceived optimal mix between public and private sectors, and the main focus was largely growing the national pie. However, as more and more options were tested, the complications turned out to be too severe to be resolved through generalized and sometimes quite

${ }^{1}$ First Author and Corresponding Author. Assistant Professor, Department of Economics, Faculty of Business and Economics, Mettu University, Ethiopia [Postal Address: Metu Zuria, Ethiopia]

Email:mlk.ishfaq@gmail.com

${ }^{2}$ Lecturer, Directorate of School Education, Government of Jammu and Kashmir, India. Email: jazrather@gmail.com

${ }^{3}$ Assistant Professor, Department of Economics, Faculty of Business and Economics, Mettu University, Ethiopia.

Email: tibebulm2@gmail.com

(c) Copyright: The Author(s)

This is an Open Access article distributed under the terms of the Creative Commons Attribution Non-Commercial License (https://creativecommons.org/licenses/by-nc/4.0/) which permits unrestricted non-commercial use, distribution, and reproduction in any medium, provided the original work is properly cited. superficial development models constructed over this period of time. Growth generally failed, the expected impacts did not materialize.

In the last quarter of the twentieth century, however, the two most populous economies started well. First, China broke away with its immediate past in a decisive way after 1978. India followed, first mildly in 1980s, then holistically after 1991, though not as spectacularly as China yet still quite impressively. In China, growth came with rather less expected impact of massive poverty reduction. Other development indicators, like infrastructure, education and longevity also improved perceptively. China's record of growth as well as poverty reduction became exemplary for policymakers in developing world. Three groups were concerned for their own objectives. Policymakers, particularly in developing countries, were concerned with appropriate polices they could learn. Economists across the world, particularly interested in growth and development, had a new experience to learn from. The business community, particularly the multinational corporations, were interested in business opportunity in China and across the world created by a new production center.

China's immediate neighbor, India, did well in 1980s compared to three decades of development efforts. However, a decisive break from the past came in 1991 when the New Economic Policy was instituted. Progress by output criterion 
was just marginally better that the previous decade. However, what mattered was growth and sustenance in a competitive environment that didn't exist before. Like China, India has both a huge population as well as a significance proportion of it living below the poverty line. Economic growth did bring a significant portion of people out of poverty. Though significantly less than that of China. Consequently, due to these and other associated reasons, the reform in China and India have received extensive attention (Huang \& Khanna 2003, Saez \& Yang 2002).

China's progress in both material and social dimensions of development has been considered miraculous by many economists and policymakers. Towards the concluding phase of the pre-reform period, policy effectiveness had reached its saturation level and economy was undergoing a state of complete stagnation. The reform brought significant vitality to the economy, which grew approximated 10 percent annually since then. The reforms started with relaxing the rules of central planning and progressed continuously to affect a more market-oriented economy. Performance of the economy not only resulted from the reforms, but also lead to further reforms. Thus, reforms and economic performance were mutually reinforcing a continuum of process.

The impressive economic performance of China was largely a result of the institutional changes in the economy juxtaposed with appropriate macroeconomic policies. The government changed the property rights regime, which provided the necessary incentives for hard work, efficiency and investment. In the initial phase this was particularly important for the primary sector. Macroeconomic policies were regularly adjusted to maintain a high growth propensity, while taking care of the stability. Variations in the growth performance reveal that the policy was more effective in China than in India. Sustained growth over this duration was maintained by constantly enhancing the supply side potential while maintaining a growing demand.

The reforms in China had many peculiar characteristics, which were not shared by other transition economies and which had a large impact on the outcome of the reforms. The process of liberalization, privatization and globalization played a significant role in laying the foundation of a vibrant economy. However, China's approach in this regard was quite different from other centrally-planned economies, either communist or otherwise, which opted to switch over to market-based or capitalist arrangement.

The main objective of this paper is to examine what factors explain the variance in the pace of reforms in China and India. This issue is important as the pace of reform also impacts their efficacy. As is evident from recent history, reform that are too fast may unleash chaos, while reforms that are too slow may stall. Thus, an understanding of the factors that influence the dynamics of reform could be useful to policymakers and leaders involved in such reforms and to investors and strategic managers evaluating market opportunities and challenges to explain the rate at which economic reforms evolve (Zahra et al, 2000). At an empirical level, this study contributes by describing the differences between the economic reforms in China and India.

\section{Relevance of Comparison between China and India}

The nature and success of development strategy of a country partly depends on the initial conditions. China and India share many commonalities in their initial conditions. But there are also noteworthy differences between the two countries. Due to these differences, as well as differences in policy perceptions, they adopted two different strategies. Consequently, their performances also varied.

The economic history of the two countries underscore that both China and India were the world's largest economies and richest countries. Maddison (2001) estimated China's and India's GDP per capita were the highest in the world in the year 1000 and their purchasing power parity (PPP) was ranked 1 and 2 in the world, respectively, from 1500 to 1870. Afterwards, failing to modernize, both countries lost their coveted status. Conditions deteriorated to the extent that both had the lowest per-capita income between 20 to 30 percent in the world.

Another important commonality is that both are the largest populous countries of the world. Together they amount to 40 percent of the total world population. Importantly, both attained freedom and became nation states immediately after the Second World War - India in 1947 and China in 1949. Also, both countries embarked on planning in early 1950s. While China adopted a complete communist system, India's arrangement was much flexible, falling in the socialist tradition. Interestingly, both these economies witnessed moderate economic growth from inception of planning to $1980 ; 4.2$ percent and 3.5 percent for China and India, respectively. After that phase both have been growing fast. However, China grew faster than India after reforms though lately growth rates of the two economies are converging.

So far as initial differences between China and India are concerned, China's per-capita income was US\$537, while India's per-capita income was higher than China (WDI). The weight of the primary sector in China was also larger than that of India in the early 1950's. In 1952, 84 percent of the total workforce in China was engaged in the agriculture sector, whereas in India only 72 percent of the workforce was engaged in agriculture. India also had a larger modern sector than China in the early 1950s.

Given the set of similarities and differences between the two countries, there is relevance looking at the successful 
development strategy of one country for the other. Therefore, it is highly appropriate to understand the dynamics of change in China because, with slight modifications, these are likely to be highly effective in India.

On a comparative basis, China systematically fairs better than India in most of the indicators, and by a significant margin. On average before 1990, China experience low and erratic growth. However, from 1992 onwards, growth in terms of GDP and showing an increasing trend. In PPP, GDP per-capita income in China in 1990 was 1522, while in India, it was 1905; India was ahead of China. However, afterwards, China's PPP GDP per-capita was always higher than India. In 2000, China's per-capita income was 3689, while India's was 2710, and it increased to 16181 in China and 6888 in India by 2018. This obviously is a large difference in economic strength of the two countries. Thus, an average Chinese citizen was more than twice richer than an Indian citizen.

Similarly, a difference is also found in case of PPP. Significant difference is not only found in economic indicators, but also in social indicators. Life expectancy at birth in China in 1990 was 69 and increased to 76.5 in 2018, while in India it was 57.8 in 1990 and increased to 69.2 in 2018. Equally, China had also experienced significant development in other indicators like in FDI as percentage of GDP and export as percentage of GDP.

As discussed above, there is significant uptake in China's development indicators from reforms. As we know in the early 1950s, both India and China adopted five-year plans to carry forward and achieve the desired results in the socio-economic fields. During the pre-reform phase, China underwent important institutional changes and towards the end the whole economy was under the control of the government. There was no private market. However, from 1978, the institutional arrangement provided progressively larger space for private sector. China's economic transformation started in the countryside with the agricultural sector as the main focus. This was followed by development of the other sectors of the rural economy spreading progressively to the rest of the economy including, notably, the foreign sector (Rao \& Pathak, 2016). This helped the reforms to benefit the rural sector and therefore the record of improvement in the development indicators in China was stronger in comparison to most of the developing or transition economies. Though liberalization, privatization, and globalization occurred in China, this was guardedly done in a phased manner so as to avoid costs of abrupt departure from the past institutional arrangement (Qazi M et. al., 2016).

In India, some reforms at decreasing the role of the bureaucratic hurdles on the economic development were introduced in the 1980s. However, after the Balance of Payment (BOP) crisis of 1991, there was an implementation of reform program aimed at opening and liberalization of most of the sectors of the economy. The emphasis was more on the industrial growth and external balance as well as provision of infrastructure and conducive environment for the services sector of the economy (Sandip et al., 2020). As the economy moved ahead the external balance with the help of institutional investment and FDI was achieved, thus, the service sector grew very fast. However, lately, the industrial sector is performing better and is becoming an important source of growth. The effectiveness of these development strategies for both the economies is analyzed hereunder.

\section{Comparative Policy Effectiveness}

The state of development in China and India in early 1980s was almost comparable. However, after reforms in China in late 1970s, and consequent economic progress, the state of development between the two countries started to diverge.

The economic policy of China was substantially more effective than that of India. The effectiveness of economic policy can be gauged from the improvement of different indicators of development. For the sake of brevity as well as to confine the analysis to our subject, we measure this effectiveness in terms of two fundamental indicators of development. The first is growth; from the instrumental perspective, growth is fundamental for ensuring and increasing the wellbeing of a society as it increases the total output of the economy. The second is growth pro-poor or not pro-poor. From the perspective of outcome, this indicator is one of the most vital to gauge the effectiveness of a policy in the long run.

\subsection{Sources of Growth in China and India}

In this study we have carried out a growth accounting exercise with a model estimated employing time-series data for China and India. The fundamental aim of growth accounting is to show changes in a country's output by the contribution from changes in its factor inputs like capital, labor and total factor productivity.

This approach is based on a production function in which output is a function of capital, labor and a residual. We have used a typical Cobb-Douglas production function with fixed factor shares:

$$
Y=A K^{\beta}(L H)^{1-\beta}
$$

Where: Y, K, A and $\beta$ are measures of output, physical capital, total factor productivity and capital share of income respectively. The capital share is assumed to be equal to 0.40 for both countries. $\mathrm{L}$ is labour, which is adjusted for educational attainment $\mathrm{H}$ as a proxy for skills. 
Capital stock are constructed using the perpetual inventory method (Beck T. et al 1999). For the subsequent years the capital stock is obtained using the following formula:

$$
K(t)=(1-\text { Depreciation }) * K_{(t-1)}+i(t)
$$

Divide equation 1 both side by labour input $\mathrm{L}$ and taking logarithms of both sides. Hence our results in terms of decomposing the growth in output per worker $\Delta \operatorname{In}\left(\frac{Y}{L}\right)$ into the contribution of growth in capital per worker $\Delta I n\left(\frac{K}{L}\right)$, increase in education per worker $\Delta \operatorname{In}(\mathrm{H})$, a residual measure of the contribution of enhancement in total factor productivity $\Delta \operatorname{In}(\mathrm{A})$ :

$$
\Delta \operatorname{In}\left(\frac{Y}{L}\right)=\beta\left[\Delta \operatorname{In}\left(\frac{K}{L}\right)\right]+(1-\beta) \Delta \operatorname{In} H+\Delta \operatorname{In} A
$$

The total factor productivity is not only a measure of technical progress but it includes other determinants of efficiency of factor usage like government policy, political conditions.

\subsection{Data}

To illustrate the growth rate of total factor productivity, we require data on output (Y), capital stock (K), labour (L), population (P) and number of years of education per worker (S). These data are collected from the following sources:

Y: Real GDP in constant 2010 LCU, these data are available World Development Indicators, World Bank.

L: Data on population refer to total population.

$\mathrm{K}$ : Capital stock.

S: Data on the stock of years of education are available (Nehru et al. 1993)

\subsection{Results Growth Accounting for China and India}

The growth accounting exercise reported in Table 1 about Chinese and India economies over the period 1978 to 2018. Choosing 1978 year corresponds to the beginning of Chinese economic reform. While dividing the period in 1993 has three purposes, to avoid the 1991 economic crises in India, it is a benchmark year for India's national accounts, and it can be acknowledged as post-reform period of India.

Table 1 shows that China's and India's average annual output growth was 9.4 percent and 5.8 percent, respectively, for the period 1978-2018. For the period 1978-1993, the growth rate of China and India was 9.1 percent and 4.6 percent, respectively. However, after 1993, the average growth rate increased to 9.5 percent and 6.6 percent for China and India, respectively. The second column shows growth in output per worker for each country. This indicator illustrates labour productivity and fetches closer to measure per capita income, which is an archetypal gauge of living standard. While output growth in India enhanced noticeably, more in the second sub-period than in China, however, the decline in labour force growth in China shows that both countries experienced a speeding-up in labour productivity growth after 1993.

The output per worker is decomposed into the contribution of physical capital per worker, education and total factor productivity. The contribution of physical capital to India's growth was quite below that of China. For instance in the entire period 1978-2018, in China physical capital contributed 2.89 percent while in India it contributed 1.25 percent. However, capital rose to some extent in India during the period 1993-2018. So far as education is concerned, its contribution remains the same in all periods and is same in both countries.

\begin{tabular}{|c|c|c|c|c|c|c|}
\hline Period & Country & GDP growth & $\begin{array}{c}\text { Output per } \\
\text { worker }\end{array}$ & $\begin{array}{c}\text { Physical } \\
\text { capital }\end{array}$ & education & $\begin{array}{l}\text { Total factor } \\
\text { productivity }\end{array}$ \\
\hline \multirow[t]{2}{*}{$1978-2018$} & China & 9.4 & 7.55 & 2.89 & 0.4 & 4.26 \\
\hline & India & 5.8 & 3.4 & 1.25 & 0.4 & 1.75 \\
\hline \multirow[t]{2}{*}{ 1978-1993 } & China & 9.1 & 6.76 & 2.4 & 0.3 & 4.06 \\
\hline & India & 4.6 & 2.5 & 0.95 & 0.3 & 1.25 \\
\hline \multirow[t]{2}{*}{$1993-2018$} & China & 9.5 & 8.33 & 2.99 & 0.4 & 4.94 \\
\hline & India & 6.6 & 5.3 & 2.3 & 0.4 & 2.96 \\
\hline
\end{tabular}

Table 1: Sources of growth: China and India, 1978-2018 


\subsection{Was Growth Pro-Poor in China and India: Measuring Pro-Poor Growth}

Given the picture of growth pattern depicted above, it is remarkable to know how growth was related with poverty. The poverty reduction debates emphasize that economic growth plays the major role to reduce poverty. The trickle-down view implies that economic growth benefits first the rich whose spending trickles down into economic gains to the poor. This was the dominant philosophy during 1950s and 1960s (Kakwani \& Pernia 2000). Dollar and Kraay (2002) analyzed this arguments with econometric methods to identify the relationship between economic growth and income of the poor and estimated growth elasticity of poverty as 1 percent, and they concluded that the income of the poor rises 1 percent with 1-percent growth. However, Ashley (2007) criticized this research on two points: first, the analysis is not robust; second, there is cross-country heterogeneity behind these cross-country studies.

In this connection, Datt and Ravallion (1992) and Kakwani (1993) offered a decomposition analysis of poverty measures into growth and redistribution components. This new contribution to poverty decomposition takes into account changes in poverty over time (Son, 2003). Kakwani and Pernia (2000) defined the concept of pro-poor growth in the context of Sen's (1976) concept of well-being in terms of functioning and capabilities. Kakwani and Pernia (2000) defined an economic growth as pro-poor if the poor benefit proportionally more than the rich. Ravallion criticized this definition because it does not take into account absolute gains of the poor, so Ravallion and Chen (2003) define the growth as pro-poor if poverty falls when growth takes place. They suggest a direct approach to identify impact of growth rates to the poor and define a growth incidence curve, showing how growth rate for a given quantile varies across quantile ranked by income.

\subsection{Measuring Pro-Poor Growth}

In the literature, numerous methods of pro-poor growth are proposed in relation to definition of pro-poor growth. Three pro-poor growth measures are used in the analysis.

The first measure of pro-poor growth, proposed by Ravalliona and Chen (2003), is based on change in the income of poor individual people using the cumulative distribution function of income, $\mathrm{F}(\mathrm{y})$. By definition, if we invert $\mathrm{F}(\mathrm{x})$ at the $\mathrm{p}^{\text {th }}$ quintile, we get the income of that quantile:

$$
y_{t}(p)=L_{t}^{\prime}(p) \mu_{t}
$$

Where $y_{t}(p)$ is the income of the $\mathrm{p}^{\text {th }}$ quantile, $\mathrm{L}_{\mathrm{t}}(\mathrm{p})$ is the Lorenz curve, $L_{t}^{\prime}(p)$ is the slope of Lorenz curve, and $\mu_{t}$ is the mean income. Indexing over time and evaluating the growth rate of income of the pth quintile, and using the above expression we get

$$
g_{t}(p)=\left[\frac{y_{t}(p)}{y_{t-1}(p)}\right]-1
$$

Where $g_{t}(p)$ is called as growth incidence curve (GIC). Growth incidence curve shows how the growth rate for a given quantile varies across quantiles ranked by income (Ravallion and Chen 2003). It follows from (5) that:

$$
g_{t}(p)=\frac{L_{t}^{\prime}(p)}{L_{t-1}^{\prime}(p)}\left(\gamma_{t}+1\right)-1
$$

Where $g(p)$ is the growth rate in the income of the pth quantile and $g_{t}(p)$ is the ratio of mean per capita income in period $t$ to that in period $t-1$. In other words, the changes in the income of an individual in the pth quantile are weighted by the shift parameter in the slope of the Lorenz curve. Cumulating Equation (6) up to the proportion of the poor (Ht) gives an equivalent expression for a change in the Watt's index of poverty:

$$
\frac{-w t}{d t}=\int_{0}^{H_{t}} \frac{\log y_{t}(p)}{d t} d p
$$

Ravallion and Chen (2003) adopted Watts index, defining pro-poor growth as the change in the poor's watts index divided by the head count index. Therefore, the pro-poor growth rate can be expressed as:

$$
I=\frac{w_{1}(z)-w_{2}(z)}{f_{1}(z)}
$$

Where $w_{t}(\mathrm{z})$ is the watts index for time 1 and 2 , and $f_{1}(z)$ is the headcount index in the first base period and $\mathrm{z}$ is the poverty line.

The second measure is the pro-poor growth index proposed by Kakwani and Pernia (2000). It introduced nexus among poverty, reducing income inequality and promoting economic growth. Then they decompose the total change in poverty into two components: impact of growth when the distribution of income does not change, and the effect of income redistribution when total income does not change. This decomposition is identified as:

$$
\delta=\eta+\zeta
$$

Where $\delta$ is proportional change in poverty when there is a positive growth rate of 1 percent. $\eta$ is the pure growth effect (percentage change) and is the inequality effect. Then pro-poor growth index is shown as:

$$
\phi=\frac{\delta}{\eta}
$$


The growth will be pro-poor if $\phi>1$, meaning that the poor benefit proportionally more than the non-poor, if $0<$ $\phi<1$, growth is not pro-poor, even though it still reduces poverty incidence and lastly if $\phi<0$, economic growth actually leads to an increase in poverty (Kakwani \& Pernia, 2000).

The last pro-poor growth measure is poverty equivalent growth rate (PEGR) proposed by Son and Kakwani (2008). This measure is taking into account both growth rate in mean income and how the benefits of growth are distributed between the poor and the non-poor. It can be seen as a measure of pro-poor growth and also as an alternative measure of the impact of inequality changes on poverty. The PEGR is defined as:

$$
\gamma^{*}=\left(\frac{\delta}{\eta}\right) \gamma=\phi \gamma
$$

$\gamma^{*}$ is the PEGR and $\gamma$ is present growth rate, $\delta$ is the growth elasticity of poverty, $\eta$ is the neutral relative growth elasticity of poverty derived by Kakwani (1993), $\phi$ is relative pro-poor growth index suggested by Kakwani and Pernia (2000). When $\gamma^{*}>\gamma$, growth is defined as pro-poor.

\subsection{Results of Measurements of Pro-Poor Growth}

The growth incidence curve (GIC) is used to determine the extent to which economic growth brings benefits to the poor. The GIC of China, as displayed in Figure 1 for the period 2000-2011, shows an inverse U-shape, which is the highest growth observed at the $20^{\text {th }}$ percentile. The propoor rate for this period was 12.5 per annum, which is above the normal growth rate of 8.81 percent. The rate of pro-poor growth was higher in this period and the distribution shifts were more pro-poor. The GIC of India as shown in Figure 2 for the period 2000-2011, is not pro-poor because growth rates increase monotonically moving from the bottom percentile to the top percentile. In this period, the pro-poor rate was around 3.4 percent, which is below the ordinary growth rate of 5.90 percent.

Table 2 presents the whole picture of the Chinese and Indian economies between 2000 and 2011. As shown in the table, per-capita household expenditure grew at an annual rate of 8.81 percent and 5.90 percent in China and India, respectively, over the 11 -year period. The head count ratio decreased at an annual rate of 12.64 in China and 4.45 in India over the period. Similarly, the poverty gap ratio and severity of poverty decreased more in China (-12.64 percent) than in India (-4.45 percent). Likewise, inequality decreased more in China compared to India, as shown in Table 2.

Poverty reduction depends on the rate of growth and redistribution due to growth. Table 5 presents the two measures of pro-poor growth, namely, pro-poor growth index (PPGI) and poverty equivalent growth rate (PEGR). According to Kakwani and Pernia (2000), the pro-poor growth index is equal to the ratio of two elasticities, and according to them, growth is pro-poor if the PPGI ratio is greater than one. However, poverty is still reduced due to the growth, which is probably a trickle-down effect. As is clear from Table 5 that China's PPGI was greater than in the period 2000-2011, which according to Kakwani and Pernia(2000) is pro-poor. As in India PPGI is less than one, it means growth was not pro poor during the same period.

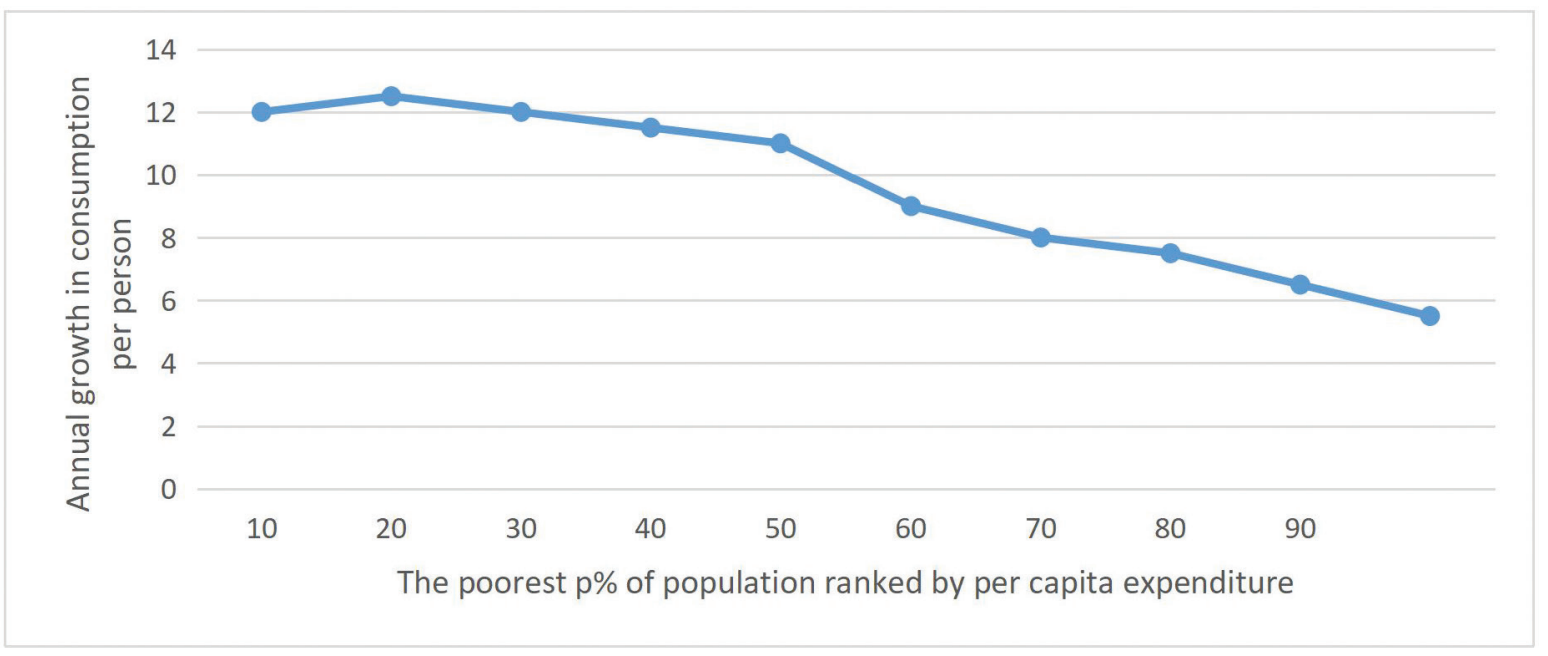

Figure 1: Growth Incidence curve for China (2000-2011) 


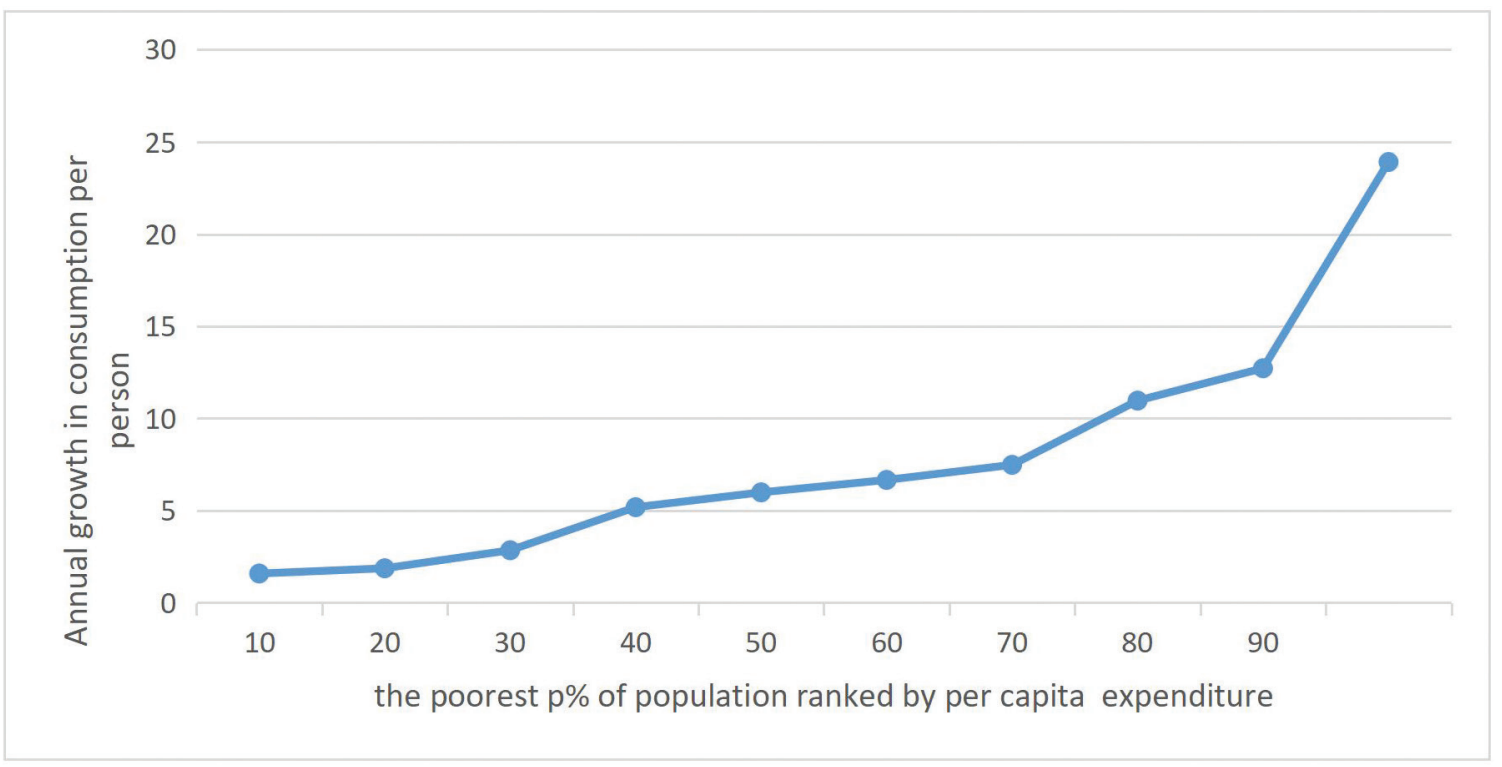

Figure 2: Growth Incidence for India (2000-2011)

Table 2: Per-capita household expenditure, Poverty and Inequality in China and India, 2000-2011

\begin{tabular}{|l|c|c|c|c|c|c|}
\hline & \multicolumn{3}{|c|}{ China } & \multicolumn{3}{c|}{ India } \\
\hline & $\mathbf{2 0 0 0}$ & $\mathbf{2 0 1 1}$ & $\begin{array}{c}\text { Percent Change } \\
\text { (Per Annum) }\end{array}$ & $\mathbf{2 0 0 0}$ & $\mathbf{2 0 1 1}$ & $\begin{array}{c}\text { Percent Change } \\
\text { (Per Annum) }\end{array}$ \\
\hline $\begin{array}{l}\text { Per-Capita Consumption } \\
\text { Expenditure }\end{array}$ & 493 & 1248 & 8.81 & 704 & 1073 & 5.90 \\
\hline Head Count Ratio & 35 & 7.91 & -12.64 & 35 & 21.20 & -4.45 \\
\hline Poverty gap ratio & 12 & 1.77 & -15.96 & 8 & 4.30 & -5.48 \\
\hline Severity of poverty & 45 & 0.61 & -16.61 & 2.75 & 1.50 & -5.36 \\
\hline Gini index & 39 & 42.22 & 0.72 & 34 & 37.8 & 0.96 \\
\hline
\end{tabular}

Table 3: Pro-poor growth measures based on poverty elasticity

\begin{tabular}{|l|c|c|c|c|c|c|}
\hline & \multicolumn{3}{|c|}{ China } & \multicolumn{3}{c|}{ India } \\
\hline Poverty Measures & $\begin{array}{c}\text { Total poverty } \\
\text { elasticity }\end{array}$ & $\begin{array}{c}\text { Pro-poor } \\
\text { growth index }\end{array}$ & $\begin{array}{c}\text { Poverty } \\
\text { equivalent } \\
\text { growth rate }\end{array}$ & $\begin{array}{c}\text { Total poverty } \\
\text { elasticity }\end{array}$ & $\begin{array}{c}\text { Pro-poor } \\
\text { growth index }\end{array}$ & $\begin{array}{c}\text { Poverty } \\
\text { equivalent } \\
\text { growth rate }\end{array}$ \\
\hline Head Count Ratio & -1.44 & 1.05 & 9.32 & 0.75 & 0.74 & 4.36 \\
\hline Poverty gap ratio & -1.81 & 1.09 & 9.65 & 0.92 & 0.85 & 5.01 \\
\hline Severity of poverty & -1.88 & 1.12 & 9.94 & 0.90 & 0.89 & 5.20 \\
\hline
\end{tabular}


The results of PEGR shows, that during 2000-2011, the PEGRs were higher than actual growth rate in China, while in India, PEGRs were less than actual growth rate, suggesting that growth in China was pro-poor and in India growth was not pro-poor.

All the above three measurements of pro-poor growth show that, during the period 2000-2011, growth was regarded as pro-poor in China and not pro-poor in India. We discuss in the next section the reasons why China's economic growth was more pro-poor than India.

\section{Lesson of China's reforms for India}

The experience of China's reform success offers substantial lessons for most developing countries. Since India has more similarities with China than most other developing countries, this experience is particularly insightful for India. Some of the policy options put in place in China's reforms have been particularly helpful in developing the institutional and technological framework for success. The major dimensions of reforms in China that could be implemented for a successful transformation of the Indian rural sector and, thus, the overall transformation of the economy, are identified below.

\subsection{Agriculture/Rural Centric}

As the reforms in China started in the rural sector, India's reforms in 1990s were more aimed at the secondary and tertiary sectors of the economy. From moderate growth in 1990 s to high growth in 2000 s, the impact of the growth on poverty reduction and rural transformation has been quite meager. The thrust on the rural sector produced output expansion, which was automatically distributed in the rural economy and, as a consequence, poverty reduction and rural transformation was speedy. This experience shows that, for large developing countries, thrust for poverty reduction should focus on rural/agricultural sector development. There has to be a renewed emphasis on rural development in India in its most comprehensive sense. This includes emphasis on proper institutional environment, technical and technological change, and substantial improvement in rural infrastructure.

\subsection{Decentralized}

The governance system of China is greatly decentralized. Villages and urban areas have their own local governance structures that cater to their local needs. The emergence of township and village enterprises (TVEs) has been a successful phenomenon because of the governance apparatus. So has the provision of different public goods both in the pre-reform and the after-reform period been provided by the local administrative mechanism. Decentralized governance has, on the one hand, provided the incentive for better economic performance as the expanded output was partly shared by the governing body. On the other hand, the provision of public goods and produced activities in the local areas has been efficient because of the involvement of the local people who are direct beneficiaries of these activities.

In comparison to China, India's decentralized governance mechanism in the form of Panchayat raj in rural areas has been largely unsuccessful. The provision of local public goods and involvement in other economic activities has been largely an engagement of the state and central governments with little intervention on the part of these institutions. This, on the one hand, has marred the incentive for the local people to produce good performance in these activities. Simultaneously, the level of corruption has been high because of the lack of effective intervention of the proposed recipients of the benefits of the schemes. Thus, to make the rural sector of the economy vibrant and well performing, decentralizing the governance of economic and other developmental activities is quite necessary as shown by the Chinese experience. Notwithstanding the need of decentralized governance system, the political scenario of India offers rather bleak environment for a successful drive for the same.

\subsection{Human Resource Development}

Not only have Chinese efforts at the human resource development been substantially higher in comparison to India, but even the way of doing it has been quite different. There has been a substantial emphasis on the technical expertise in the areas of economic activities rather than a theoretical focus on subjective issues. The main emphasis of Mao's rustication process, though stopped after the Cultural Revolution, was actually meant to contribute to the economy. However, the emphasis on the technological knowhow for average student has been kept intact.

The performance of the Indian economy has been marred by the absence of an educated and skilled workforce. For the economy to perform well, there has to be a special emphasis on the development of the quality of the labor market in terms of the level of education and skills. For that, India has to accentuate its efforts at human resource development through a quantum leap.

\section{Conclusions}

The expansion of the Chinese economy in the aftermath of the reforms initiated in the late 1970s, with its profound impact on the development indicators, has been one of the most outstanding success stories of any economies in recent times. Much of this changed state of the Chinese economy had favorable economic and social consequences for the Chinese 
people. In the past three decades, China was the fastestgrowing economy of the world. This was the result of a stream of reforms initiated in late 1970s. Towards the concluding phase of the pre-reform period, policy effectiveness had reached saturation level and the economy was undergoing a state of complete stagnation. The introduction of reforms changed the whole scenario, brought significant vitality to the economy, which grew approximated 10 percent annually since then. The reforms started with relaxing the rules of central planning and progressed continuously to affect a more market-oriented economy. The total gross value output of the primary state of development in China and India in early 1980s was almost comparable.

However, after reforms in China in late 1970s, and consequent economic progress, the state of development between the two countries started to diverge. Despite good growth record after the reforms in last decade of the twentieth century, India failed to reduce poverty at a reasonable pace and to bring about a transformation of its rural economy. The economic policy of China was more effective than India's. The effectiveness of economic policy can be measured by different indicators of development. So, in this context, effectiveness was gauged in terms of two fundamental economic concepts. First, growth accounting model employing time-series data of China and India to know the contribution of factor inputs like capital, labour and total factor productivity in countries output during the period 1978 to 2018. The results of the growth accounting model shows that, during 1978-2018, annual average GDP growth was 9.4 percent and 5.8 percent in China and India, respectively. The study found that Chinese economic growth was pushed by total factor productivity.

The second economic concept relates to pro-poor growth and anti-poor growth; numerous methods of propoor growth are proposed, however, this study used three pro-poor growth measures. The first measure proposed by Ravallion and Chen, is known as growth incidence curve; the second measure is proposed by Kakwani and Pernia, and the last measure is poverty equivalent growth rate (PEGR) proposed by Kakwani and Son. The results of these three pro-poor growth measures show that growth was pro-poor in China and anti-poor in India. China's reform experience has important lessons for India's economy in the following three areas: a renewed thrust on the rural economy and primary sector, as India with its predominant rural population will benefit more from rural-biased economic policies; decentralized planning and execution because it will increase the appropriateness and effectiveness of economic incentives and investments; and a much larger investment on human resource development with emphasis on health, education and most importantly skills development in the countryside. However, to be effective, all of these measures must evolve from the existing institutional arrangement with significant caution on compatibility with domestic culture.

\section{References}

Ashley, R. (2007). Growth may be good for the poor, but decline disastrous: On the non-robustness of the Dollar-Kraay result. International Review of Economics and Finance, 17, 338-338. https://doi.org:10.1016/j.iref.2007.09.001.

Beck, T., Levine, R., \& Loayza, N. (1999). Finance and the Sources of Growth. Policy Research Working paper, no. 2057. The World Bank

Datt, G., \& Ravallion, M. (1992). Growth and redistribution components of changes in poverty measures: A decomposition with application to Brazil and India in the 1980s. Journal of Development Economics, 38(2), 275-295. https:// doi://10.10101016/0304-3878(92)90001-p

Dollar, D., \& Kraay, A. (2002). Growth is Good for the Poor. Journal of Economic Growth, 7, 195-225. https:// doi://10.1023/A:1020139631000.

Huang. Y., \& Khanna. T. (2003). Can India Overtake China? Foreign Policy Newsletter, retrieved December 25, 2019, from http://foreignpolicy.com/2003/07/01/can-india-overtake-china

Kakwani, N., \& Pernia, E. (2000). What is Pro-Poor Growth, Asian Development Review, Asian Development Bank, 16(1), 1-22.

Kakwani, N. (1993). Poverty and Economic Growth with Application to Cote D Ivoire, Review of Income and Wealth, 39(1), 121-139, https://doi.org/10.1111/j.1475-4991.1993. tb00443.x

Maddison, A. (2001). The World Economy: A Millennial Perspective, Paris: Development Centre of the OECD. ISBN: 92-64-18998-X,

Nehru, V., Swanson, E., \& Dubey, A. (1993). A New Database on Human Capital Stock: Sources, Methodology and Results. World Bank Policy Research Working Papers, Washington, DC: World Bank.

Qazi, M., Hye, S., \& Wee-Y. (2016). The Impact of Trade Openness on Economic Growth in China: An Empirical Analysis. Journal of Asian Finance, Economics and Business, 3(3), 27-37. https:// doi.org/10.13106/jafeb.vol3.no3.27.

Rao, T., \& Pathak R. (2016). China's Ascent in World Trade and Associated Shifts in Its Trade Structure. Journal of Asian Finance, Economics and Business, 3(3), 39-55. https://doi. org:/10.13106/jafeb.2016.vol13.no3.39.

Ravallion, M., \& Chen, S. (2003). Measuring Pro-Poor Growth, Economics Letter, 78(1), 93-99, https://doi.org/10.1016/s01651765(02)00205-7

Saez, L., \& Yang, J. (2002). The deregulation of state-owned enterprises in India and China. Comparative Economic Studies, 43(3), 69-97. https://doi.org/10.1057/ces.2001.14

Sandip, S., Krishna, M., \& Asmita, C. (2020). Sectoral Contribution to Economic Development in India: A Time Series Co-Integration 
Analysis. Journal of Asian Finance, Economics and Business, 7(9), 191-200. https://doi.org/10/13106/jafeb.2020.vol7.no9.191

Sen, A. (1976). Poverty: An Ordinal Approach to Measurement, Econometrics, 44(2), 219-231, https://doi.org/10.2307/1912718

Son H. H., \& Kakwani. N. (2008). Poverty Equivalent Growth Rate, Review of Income and Wealth, 54(4), 643-655. https:// doi.org/10.1111/j.1475-4991.2008.00293.x
Son, H. (2003). A New Poverty Decomposition. Journal of Economic Inequality, 1(2),1-7, https://doi.org/10.1023/A:1026 122624752

Zahra, S., Ireland, R., Isabel, G., \& Michael, (2000). Privatization and Entrepreneurial Transformation: Emerging Issues and a Future Research Agenda. The Academy of Management Review, 25(3), 509-524. https://doi.org/10.2307/259307 